\title{
On National Music Theory Teaching Reform in Colleges
}

\author{
Ying Qin \\ School of Music \\ Huanghe Science and Technology College \\ Zhengzhou, Henan, China
}

\begin{abstract}
As for the college students specialized in national music, the important learning task is to grasp the theory knowledge of national music and strengthen their own music achievement in the learning process, which will affect students' innovation and development in the field of music in the future. National music is the national characteristic, and one of the major forms of national culture. Colleges shall pay enough attention to national music teaching. But there are still many inevitable problems in the actual teaching process. This paper has made analysis in combination with the necessity of carrying out music theory teaching based on the above mentioned, finds out the problems exist in current teaching process, and then discusses several reform forms of effective teaching for reference.
\end{abstract}

Keywords-colleges; national music theory; classroom teaching; teaching reform

\section{INTRODUCTION}

To develop music art education in colleges is to further improve students' music cultural theory knowledge, promote the improvement of students' music skills and music accomplishment, enabling students to be the excellent music professionals, so as to better meet the demand of social development. The national music theory course in music teaching is mainly to inherit and carry forward the national culture spirit, making the national music realize integration and innovation of diversified styles, so as to achieve the purpose of expanding the influence of national art culture. This paper has made analysis on the necessity of carrying out national music theory teaching activities, and the problems exist in actual application, and make further discussion from the aspects of teaching reform, to strengthen the influence of national music in the field of music art.

\section{NECESSITY OF CARRYING OUT NATIONAL MUSIC THEORY TEACHING ACTIVITIES IN COLLEGES}

\section{A. Improve Students' Sense of National Pride through National Music Theory Teaching}

Carrying out national music teaching activities is the main form of carrying forward and developing regional ethnic characteristics. The students specialized in music participate in national music learning can not only fully stimulate students' love of national music, but also can strengthen students' understanding and recognition of national music, enhance students' sense of national pride and identity, at the same time, can also better promote the development of students' comprehensive quality, enabling students to form the correct values of life. With the strengthening of the development trend of economic globalization, the cultural exchange between countries is becoming closer. In order to further enhance core competitiveness of talents, it is necessary to arrange national music theory course into the teaching system of music professional students, to enhance the comprehensive quality and professional skills of college students, so as to make it one of the main ways for spreading and developing Chinese culture.

\section{B. Significance of Strengthening Cultural Construction through National Music Theory Teaching}

National music represents the local culture, containing the traditional national culture and the essence of historical inheritance, having a long history and profound historical accumulation. Carrying out national music theory teaching course in colleges is to further enhance students' understanding and recognition of the regional and even traditional Chinese culture, which may not only broaden the students' music learning view, but also can make students experience the national spirit reflected by the national music, promoting the progress of China's socialist spiritual civilization construction. The Chinese excellent culture can be inherit and developed very well through college students' learning and deepening; we shall make Chinese culture be spread all over the world gradually in a powerful manner with colleges as the platform, enabling China to better achieve the construction of great cultural country.

\section{Change the National Music Teaching through National Music Theory Teaching}

The development and progress of social economy and culture will play certain role in promoting college teaching reform. It is one of the teaching designs need to be planned by the colleges with emphasis to improve teachers' teaching effectiveness and enhance the students' knowledge and skills [1]. Teaching reform is to promote colleges to change the traditional teaching pattern gradually, make teaching means innovation, and enable college students to understand the pleasure and importance of the course learning. As for national music theory teaching, teachers are still needed to have enough theoretical knowledge, solid foundation of music to carry out teaching activities, and express their own view of national 
music reasonably, promote the reform and innovation of national music theory teaching, enabling students to be influenced by teachers' personality charm, so as to arouse students' understanding and reflection on national music, and change the national music theory teaching in China.

\section{CURRENT Situation OF NATIONAL Music TheORY TEACHING IN COLLEGES}

\section{A. Separation of Theoretical Education and Practical Teaching}

Sufficient practical experience is needed for theoretical knowledge learning to obtain a more profound understanding and apperception. The connotation of theoretical knowledge can only be enhanced by combining theoretical knowledge and practical experience effectively, and national music theory teaching in colleges is no exception. In order to enhance students' understanding of music theory knowledge and improve their application ability, it is necessary to increase practical courses to the teaching content, enabling students to discover the charm and profound connotation of national music in the process of experience, communication, and exploration. But in the actual teaching process, the national music theory teaching is still defined as pure theoretical teaching in the syllabus in most colleges, without combining with practice class, and related seminar arrangement, but only complete teaching mission by the boring course teaching. Such teaching method will not only reduce students' learning enthusiasm, but also will make the national music lose its application vitality, affecting the innovation and development of national music.

\section{B. Insufficient Profundity of National Music Theory Teaching}

There is certain deviation in the teaching objective orientation of national music theory course in most colleges. The contents of enhancing students' learning skills, playing a positive role in carrying forward Chinese traditional national culture's spirit and value, and the promoting national music teaching reform are not mentioned in the teaching objective, but the utilitarianism is reflected, which is bad for the development of national music to some extent. And as for application of teaching methods, most college teachers still choose the traditional teaching form, namely the pure theoretical teaching, with teachers as the main body in the class to teach students the boring music theory, which has reduced the enthusiasm of students' learning. At the same time, it is bad for students to understand the real national music. As for the selection of music content, teachers have not kept pace with the times, but still use traditional teaching material, which will make students be unable to contact with the real level of national music; more novel elements will be blended in national music along with the open development characteristic, to add the characteristics of national music, enabling national music to be loved and collected by more people. But teachers' teaching material hasn't connected with modern national music, which will make students have a smattering of knowledge in the process of learning.

\section{Laggard Teaching Means of National Music Theory}

The development of science and technology has brought a lot of convenience to the society. As for classroom teaching in colleges, vitality will be added via the application of multimedia technology, which has more advantages compared with traditional music class. But teachers still believe that theoretical course needs to be treated seriously while the national music theory teaching is conducted in most colleges, without setting the teaching situation or arranging the teaching activities fully combining multimedia technology, but to teach using the blackboard, ask the students to read books, aiming to deposit students' blundering psychology through this teaching means, and make students consult and think about the theoretical knowledge and points of view relating national music theory from the teaching material calmly. But accepting the boring theory for a long time is difficult ensure students keep energetic for a long time, thus their enthusiasm in learning is reduced; students' thinking activity and potential is limited, which has reduced the teacher's teaching effect as a whole.

\section{Key Points of National Music Theory Teaching REFORM IN COLLEGES}

\section{A. Strengthen the Combination of Music Theory Teaching and Practice}

It is easy to be tired and irritable in the dull and simple learning environment for a long time. Therefore, it is necessary to conduct reform for the traditional music teaching class to further improve teacher's teaching effect and improve the students' knowledge and skills in national music theory teaching, namely, strengthen the combination of music theory teaching and practice activities, enabling students to transform their mentality from passive acceptance of knowledge to positive pursuit and excavation of national music charm in practice gradually [2]. First of all, as for the arrangement of teaching form, practice communication course is needed to add to the theory teaching class in combination with the famous national music plays in our country, such as scene layout, conception, background and profound connotation and so on to explain. Teachers can also use multimedia equipment reasonably, enabling students to feel and appreciate the real national music directly, adding students' feeling about beauty in terms of visual, auditory, etc. Second is the set of teaching situation. Teachers can introduce in the author's background information as appropriate in combination with actual teaching content, such as the introduction about celebrity anecdotes, to make the classroom teaching content more interesting, thus to effectively enhance students' enthusiasm of participating in classroom activities. The last is the guidance of practice activities. Teachers can ask students carry out the extracurricular practice activities according to their own interest module, such as the investigation report of national music, exchange meeting or chorus competition, etc., and complete the activity report, enabling students to understand the deeper national music in the process of practice, promoting the improvement of students' own music accomplishment. 


\section{B. Increase the Theoretical Knowledge Teaching Channels of National Music}

Teachers shall not require students to learning national music theoretical knowledge by mechanical memorizing, but to make students be fully integrated into the national music environment structure, and to take initiative to recognize, understand and feel the current national music characteristic. Therefore, teachers shall integrate the current cultural knowledge into the theory learning in combination with the social knowledge and background of national music, rendering students more space to think and understand the interoperability between the old and new knowledge and the connotation. At the same time, it is still necessary to increase the channels for understanding the theoretical knowledge [3]. The beautiful music pays more attention to the audience's feelings, and the media for music entering into the audiences' heart is auditory perception. The national music appreciation course shall be arranged by fully combining with the teaching resources and material by the teachers, making students to truly feel and understand the national characteristics or patriotism reflected by the national music. Only the feelings that are truly integrated in heart can be called the real experience. So as for the aspect of teaching model reform, teachers can carry out more music audition links, to nurture students' national music accomplishment through music audition, exercise students' national music appreciation ability, and fully stimulate students' learning enthusiasm.

\section{Master the Essentials of National Music Teaching Theory}

Set up the course of national music theory teaching to cultivate more excellent music professionals. Students can only obtain the more professional music skills by solid foundation in music theory knowledge reserves, to meet the needs of music art development for professionals in the future. Therefore, when arranging national music theory course teaching in colleges, it is necessary to add appropriate theory knowledge teaching in the training courses of music playing techniques, enabling students to improve their own music accomplishment through the study of national music theoretical knowledge, and upgrade their own music skills gradually in combination with the practice experience, to gain a more comprehensive development and progress. Therefore, while carrying out national music theory teaching activities, colleges shall pay attention to set the course's teaching goal in the contents of improving students' music accomplishment.

\section{Expand the National Music Theory Teaching Resources}

With the historical evolution and development, national music art has also gained greater improvement and progress, and has fully combined the modern music element in terms of artistic form and obtained more abundant and full expression. Therefore, as for the college national music theory teaching, attention shall be paid to the exploration and innovation, to find out the appropriate teaching methods and show the charm of modern national music art. Therefore, the national music theory teaching resources can be expanded [4]. In order to meet students' exploration and pursuit of current national music knowledge, colleges shall make reasonable use of computer network technology, to add national music theory teaching resources, providing teachers and students with more channels and ways to understand national music. At the same time, teachers can also compiling the teaching materials of national music theory that is in line with the local characteristics and suitable for local propaganda in combination with a large number of real materials, making the national music forms more diverse.

\section{CONCLUSION}

National music is an important form to show China's history and culture. If colleges open up this course, they should pay attention to change the traditional teaching mode, realize the teaching reform, with the content including giving priority to improve students' national music accomplishment and carry forward China's nationalism in terms of teaching goal setting; as for teaching forms, teaching mode and teaching means, they shall be made based on the practice, pay attention to the combination of theory and practice and reasonably use multimedia technology, enabling students to feel the charm of national music and enhance the effectiveness of national music theory teaching.

\section{REFERENCES}

[1] Luo Jie. Analysis of National Music Theory Teaching Reform in Colleges [J]. Journal of Jiamusi Education Institute, 2013（10） : 149.

[2] He Jiao. Suggestions for National Instrumental Music Teaching Reform in Nationalities Universities [J]. Music Space, 2015 (05) : 140-141.

[3] Luo Danyang. Analysis of National Music Theory Teaching Reform in Colleges [J]. National Music, 2014 (06) : 118-119.

[4] Zhang Mi. Research on Reform Strategy of National Music Teaching in General Universities [J]. Yalujiang Literature Monthly (Second Half): 2014 (07) : 289 . 